\title{
Melodorum leichhardtii (F.Muell.) Benth. Extracts Inhibit the Growth of Klebsiella pneumoniae
}

\author{
Getmore Chikowe', Lindiwe Mpala', Ian Edwin Cock, ${ }^{1,2, *}$ \\ School of Environment and Science, Griffith University, 170 Kessels Rd, Nathan, Brisbane, Queensland 4111, AUSTRALIA \\ 2Environmental Futures Research Institute, Griffith University, 170 Kessels Rd, Nathan, Brisbane, Queensland 4111, AUSTRALIA.
}

\begin{abstract}
Introduction: Melodorum leichhardtii F.Muell. Benth. is a rainforest vine which is native to north-eastern rainforest regions of Australia. Melodorum spp. are rich in a variety of terpenoids with reported antibacterial activity. Despite this, $M$. leichhardtii leaf extracts have not previously been examined for bacterial growth inhibitory properties. Methods: The antimicrobial activity of a methanolic $M$. leichhardtii leaf extract was investigated by disc diffusion and growth time course assays against a panel of bacterial pathogens. The growth inhibitory activity was further quantified by MIC determination. Toxicity was determined using the Artemia franciscana nauplii bioassay. Results: The methanolic $M$. leichhardtii leaf extract was a potent inhibitor of Klebsiella pneumonia (MICs of $388 \mu \mathrm{g} / \mathrm{mL}$ ). The extract was also a low-moderate inhibitor of $B$. cereus growth (MICs $3678 \mu \mathrm{g} / \mathrm{mL}$ ) but was completely devoid of inhibitory activity against all other bacterial species tested. The antibacterial activity of the methanolic M. leichhardtii leaf extract was further investigated by growth time course assays that showed significant growth inhibition in cultures of $K$. pneumoniae and $B$. cereus within $1 \mathrm{~h}$ of exposure. All extracts were determined to be nontoxic
\end{abstract}

\section{INTRODUCTION}

Plants produce a wide variety of secondary compounds, which provide them characteristic pigment, odour and flavour characteristics, may also give them antimicrobial properties. ${ }^{1}$ Traditional plant derived medicines have been used in most parts of the world for a variety of therapeutic purposes, including fighting microbial disease. Indeed, the ability of plant extracts to block the growth of pathogenic bacteria has become a focus of recent study. ${ }^{2-3}$ Much of the research into traditional medicinal plant use has focused on Asian, ${ }^{4}$ African ${ }^{5}$ and South American ${ }^{6}$ plants. However, the therapeutic potential of the flora of Australia has also received recent attention. The first Australians had well-developed medicinal systems and understood the therapeutic properties of a wide variety of Australian plants and how to use them effectively. ${ }^{7}$ Despite this, relatively few studies have rigorously examined the antibacterial activity of Australian native plants, although there has recently been a substantial increase in interest in this field.

Melodorum leichhardtii (F.Muell.) Benth. (family Annonaceae; commonly known as zig-zag vine, acid drop vine, merangara, wild banana; synonyms Rauwenhoffia leichardtii (F.Muell.) Diels, Fissistigma leichardtii (F.Muell.) Merr., Unona Leichardtii F.Muell.) is a vigorous climbing shrub which is native to rainforest regions of north eastern Australia. The vine has dark green alternate leaves which are lanceolate, with entire margins and grow $5-20 \mathrm{~cm}$ long by $2-7 \mathrm{~cm}$ wide (Figure 1a). Orange/brown flowers form opposite the leaves (Figure 1b) and develop into fleshy orange peanut shaped fruit (Figure 1c). The fruit are edible and have a pleasant acidic flavour. The first Australians consumed these fruit fresh off the forest floor. The stems and bark of this species was used treat some tumours and have been shown to be effective at inhibiting the proliferation of some cell lines. ${ }^{8}$

The leaves have been reported to be partictiarly rich in sesquiterpenoids, including $\alpha$-eudesmol (Figure 1d), $\beta$-eudesmol (Figure 1e), $\beta$-carophyllene (Figure 1f) and bicyclogermacrene (Figure 1g), as well as the monoter- in the Artemia franciscana nauplii bioassay, indicating their safety for use in preventing diseases caused by these pathogens. Conclusion: The lack of toxicity of the $M$. leichhardtii leaf extracts and their growth inhibitory bioactivity against $K$. pneumoniae and $B$. cereus indicate their potential in the development of new therapies targeting these bacteria.

Key words: Annonaceae, Zig-zag vine, Australian plant, Traditional medicine, Antibacterial, Ankylosing spondylitis, Eudesmol.

\section{Correspondence:}

\section{Dr. Ian Edwin Cock}

${ }^{1}$ School of Environment and Science, Griffith University, 170 Kessels Rd, Nathan, Brisbane, Queensland 4111, AUSTRALIA.

${ }^{2}$ Environmental Futures Research Institute, Griffith University, 170 Kessels Rd, Nathan, Brisbane, Queensland 4111, AUSTRALIA.

Tel: +61 737357637

E-mail: I.Cock@griffith.edu.au

DOI: 10.5530/pc.2019.1.4. penoid $\alpha$-pinene (Figure 1h). ${ }^{9}$ Interestingly, many of these terpenoids have potent antibacterial activity ${ }^{10}$ and this species may therefore also be useful in blocking bacterial infections. Despite this, antibacterial studies of $M$. leichhardtii leaves are lacking. The current study was undertaken to screen of $M$. leichhardtii leaf extracts for growth inhibitory properties against a panel of pathogenic bacteria.

\section{MATERIALS AND METHODS}

\section{Plant collection and extraction}

Melodorum leichhardtii (F.Muell.) Benth. leaves were obtained from Philip Cameron, senior botanical officer, Mt Cootha Botanical Gardens, Brisbane, Australia. The leaf samples were dried in a Sunbeam food dehydrator and stored at $-30^{\circ} \mathrm{C}$. Prior to use, the dried leaves were freshly ground to a coarse powder and $1 \mathrm{~g}$ quantities were weighed into separate tubes. A volume of $50 \mathrm{~mL}$ methanol (Ajax Fine Chemicals, Australia) was added and the plant material was extracted for $24 \mathrm{hrs}$ at $4^{\circ} \mathrm{C}$ with gentle shaking. The extract was filtered through filter paper (Whatman No. 54) under vacuum, followed by drying by rotary evaporation in an Eppendorf concentrator 5301. The resultant pellet was dissolved in $10 \mathrm{~mL}$ sterile deionised water (containing $1 \%$ DMSO). The extracts were passed through $0.22 \mu \mathrm{m}$ filter (Sarstedt) and stored at $4^{\circ} \mathrm{C}$ until use.

\section{Qualitative phytochemical studies}

Phytochemical analysis of the $M$. leichhardtii leaf extracts for the presence of saponins, phenolic compounds, flavonoids, phytosteroids, triterpenoids, cardiac glycosides, anthraquinones, tannins and alkaloids was conducted by standard assays. ${ }^{11-13}$

\section{Antibacterial screening \\ Test microorganisms}

All media was supplied by Oxoid Ltd., Australia. The reference strain of Klebsiella pneumoniae (ATCC31488) was purchased from American 


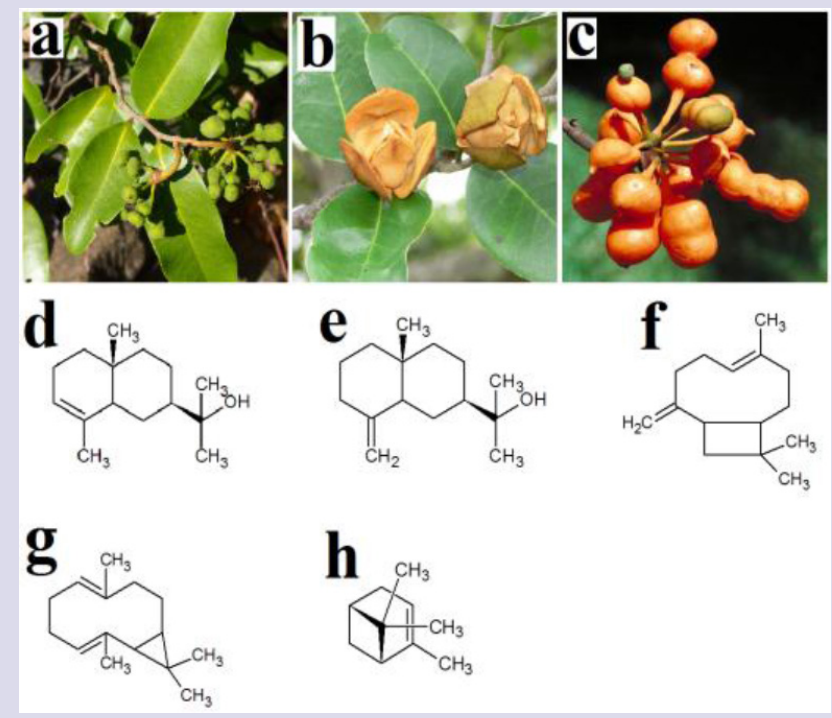

Figure 1: $M$. leichhardtii (a) leaves, (b) flowers, (c) fruit, as well as the phytochemical compounds (c) a-eudesmol, (d) $\beta$-eudesmol, (e) $\beta$-carophyllene, (f) bicyclogermacrene and (g) $\alpha$-pinene.

Tissue Culture Collection, USA. All other bacterial species were clinically isolated strains and were obtained from the School of Natural Sciences teaching laboratory, Griffith University. All stock cultures were subcultured and maintained in nutrient broth at $4^{\circ} \mathrm{C}$.

\section{Evaluation of antimicrobial activity}

Antimicrobial activity of the $M$. leichhardtii extracts was determined using a modified disc diffusion assay. ${ }^{14-16}$ Briefly, $100 \mu \mathrm{L}$ of each bacterial culture was grown in $10 \mathrm{~mL}$ of fresh nutrient broth until they reached a count of $\sim 10^{8}$ cells $/ \mathrm{mL}$. A volume of $100 \mu \mathrm{L}$ of the bacterial suspension was spread onto nutrient agar plates and the extracts were tested for antibacterial activity using $5 \mathrm{~mm}$ sterilised filter paper discs. Discs were infused with $10 \mu \mathrm{L}$ of the plant extract, allowed to dry and placed onto the inoculated plates. The plates were allowed to stand at $4^{\circ} \mathrm{C}$ for $2 \mathrm{~h}$ before incubation at $30^{\circ} \mathrm{C}$ for $24 \mathrm{~h}$. The diameters of the zones of inhibition (ZOIs) were measured to the closest whole millimetre. Each assay was performed three times in triplicate $(n=9)$. Mean values $( \pm$ SEM) are reported in this study. Standard discs of ampicillin $(10 \mu \mathrm{g})$ and chloramphenicol $(10 \mu \mathrm{g})$ were obtained from Oxoid, Australia and were used as positive controls to compare antibacterial activity. Filter discs infused with $10 \mu \mathrm{L}$ of distilled water were used as a negative control.

\section{Minimum inhibitory concentration (MIC) determination}

The minimum inhibitory concentration (MIC) of each extract against susceptible bacteria was determined as previously described. ${ }^{17-18}$ Briefly, the methanolic $M$. leichhardtii leaf extract was diluted in deionised water and tested across a range of concentrations. Discs were infused with $10 \mu \mathrm{L}$ of the test dilutions, allowed to dry and placed onto the inoculated plates. The assay was completed as outlined above and graphs of the zone of inhibition versus concentration were plotted for each extract. Linear regression was used to determine the MIC values of each extract.

\section{Bacterial growth time course assay}

Bacterial growth time course studies were performed as previously described. ${ }^{19}$ Briefly, $3 \mathrm{~mL}$ of Bacillus cereus (clinical isolate) and Klebsiella pneumoniae (ATCC31488) in nutrient broth were individually added to $27 \mathrm{~mL}$ nutrient broth containing $3 \mathrm{~mL}$ of $10 \mathrm{mg} / \mathrm{mL}$ of the extract to give a final concentration of $1000 \mu \mathrm{g} / \mathrm{mL}$ in the assay. The tubes were incubated at $30^{\circ} \mathrm{C}$ with gentle shaking. The optical density was measured hourly at $550 \mathrm{~nm}$ for a $6 \mathrm{~h}$ incubation period. Control tubes were incubated under the same conditions but without the extract. All assays were performed in triplicate.

\section{Toxicity screening}

\section{Reference toxin for toxicity screening}

Potassium dichromate $\left(\mathrm{K}_{2} \mathrm{Cr}_{2} \mathrm{O}_{7}\right)$ (AR grade, Chem-Supply, Australia) was prepared as a $4 \mathrm{mg} / \mathrm{mL}$ solution in distilled water and was serially diluted in artificial seawater for use in the Artemia franciscana nauplii bioassay.

\section{Artemia franciscana nauplii toxicity screening}

Toxicity was tested using an adapted Artemia franciscana nauplii lethality assay. ${ }^{20-22}$ Briefly, $400 \mu \mathrm{L}$ of seawater containing approximately 48 (mean $47.6, \mathrm{n}=125, \mathrm{SD} 13.2$ ) A. franciscana nauplii were added to wells of a 48 well plate and immediately used for bioassay. A volume of $400 \mu \mathrm{L}$ of diluted plant extracts or the reference toxin were transferred to the wells and incubated at $25 \pm 1^{\circ} \mathrm{C}$ under artificial light (1000 Lux). A $400 \mu \mathrm{L}$ seawater negative control was run in triplicate for each plate. All treatments were performed in at least triplicate. The wells were checked at regular intervals and the number of dead counted. The nauplii were considered dead if no movement of the appendages was detected within 10 seconds. After $24 \mathrm{~h}$, all nauplii were sacrificed and counted to determine the total $\%$ mortality per well. The $\mathrm{LC}_{50}$ with $95 \%$ confidence limits for each treatment was determined using probit analysis.

\section{Statistical analysis}

Data are expressed as the mean \pm SEM of at least three independent experiments. One way ANOVA was used to calculate statistical significance between control and treated groups with a $P$ value $<0.01$ considered to be statistically significant.

\section{RESULTS}

\section{Liquid extraction yields and qualitative phytochemical screening}

Extraction of $1 \mathrm{~g}$ of dried and powdered M. leichhardtii leaves with methanol yielded $135 \mathrm{mg}$ of dried extract (Table 1). The extract was resuspended in $10 \mathrm{~mL}$ of deionised water (containing 1\% DMSO), resulting in an extract concentration of $13.5 \mathrm{mg} / \mathrm{mL}$. Qualitative phytochemical studies showed that the extract contained high levels of phenolics, phytosterols and flavonoids, as well as moderate levels of tannins and triterpenoids. Lower levels of alkaloids were also detected in the extract whilst cardiac glycosides and saponins were completely absent or below the detection thresholds for these assays.

\section{Antimicrobial activity}

To determine the growth inhibitory activity of the M. leichhardtii leaf extract against a panel of human bacterial pathogens, aliquots $(10 \mu \mathrm{L})$ of each extract were screened in the disc diffusion assay. The M. leichhardtii leaf extract only inhibited the growth of $K$. pneumoniae and B. cereus and was completely ineffective against all other bacterial species (Figure 2). The inhibition of K. pneumonia was particularly noteworthy, with a zone of inhibition of $21 \pm 1.8 \mathrm{~mm}$ determined for this bacterium. The potency of this extract compared well with that of the positive control antibiotics ampicillin and chloramphenicol, each of which were tested at high doses $(10 \mu \mathrm{g} / \mathrm{disc})$. Indeed, the M. leichhardtii extract produced similar sizes zones of inhibition (ZOIs) as the chloramphenicol discs $(21.3 \pm 1.3 \mathrm{~mm})$ and substantially larger than the ampicillin ZOI $(10.3 \pm 0.6 \mathrm{~mm})$. 


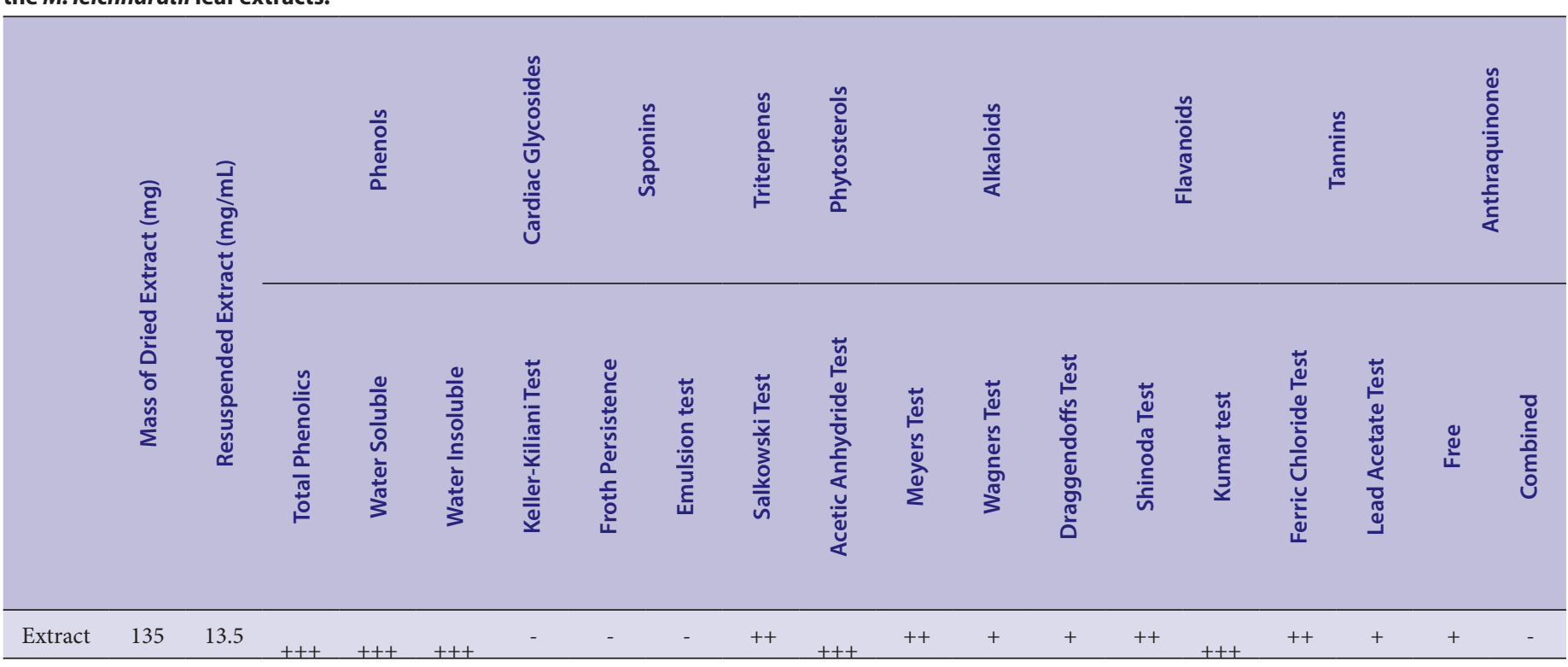

+++ indicates a large response; ++ indicates a moderate response; + indicates a minor response; - indicates no response in the assay.

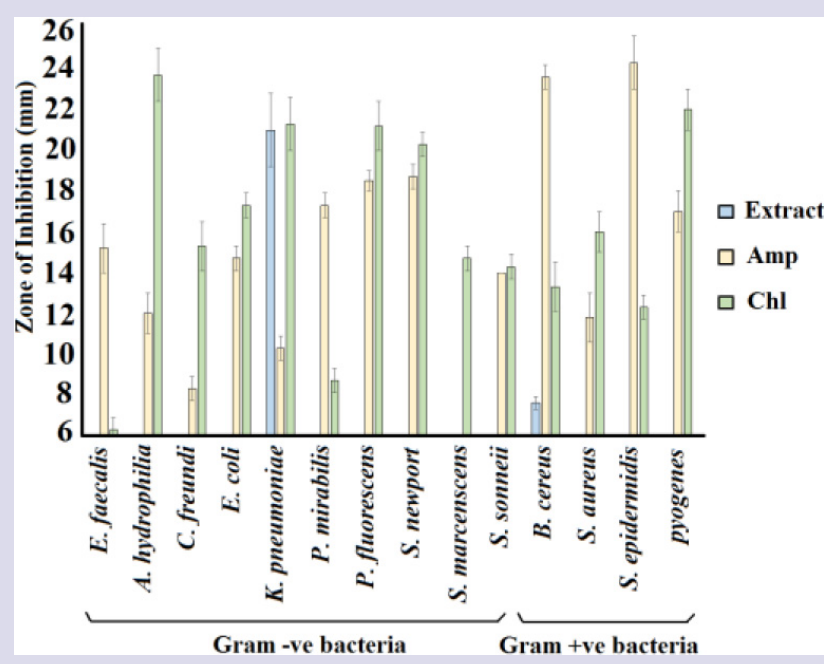

Figure 2: Growth inhibitory activity of $M$. leichhardtii leaf extracts and reference antibiotics against various bacterial species measured as zones of inhibition $(\mathrm{mm}) \pm \mathrm{SEM}$.

Blue bars represent the growth inhibition activity of the M. leichardtii extract; Yellow bars represent the growth inhibition activity of ampicillin standard discs $(10 \mu \mathrm{g})$; Green bars represent the growth inhibition

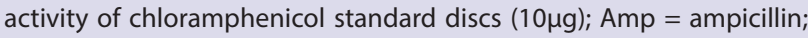
$\mathrm{Chl}=$ chloramphenicol. All assays were completed three times, each with internal triplicates $(n=9)$ and the results are expressed as mean zones of inhibition $(\mathrm{mm}) \pm \mathrm{SEM}$.

The antimicrobial efficacy was further quantified by determining the MIC value. K. pneumoniae was particularly susceptible to the methanolic M. leichhardtii leaf extract with an MIC value of $388 \mu \mathrm{g} / \mathrm{mL}(<4 \mu \mathrm{g}$ infused into the disc). As K. pneumoniae can trigger ankylosing spondylitis in genetically susceptible people,$^{23-25}$ this extract may be useful for preventing this disease (and other diseases caused by this bacterium). The extract also showed moderate growth inhibitory activity towards B. cereus, with an MIC of $3678 \mu \mathrm{g} / \mathrm{mL}$ ( $37 \mu \mathrm{g}$ infused into the disc).

\section{Bacterial growth time course assay}

The antibacterial activity of the $M$. leichhardtii leaf extracts was further investigated in B. cereus (Figure $3 \mathrm{a}$ ) and $\mathrm{K}$. pneumoniae (Figure $3 \mathrm{~b}$ ) by bacterial growth time course assays in the presence and absence of the methanolic M. leichhardtii extract. The starting concentration of the extract used in these assays was $1000 \mu \mathrm{g} / \mathrm{mL}$. The M. leichhardtii extract significantly inhibited B. cereus (Figure 3a) and K. pneumoniae (Figure 3b) growth within $1 \mathrm{~h}$, indicating a rapid antimicrobial action. The absorbance of the B. cereus culture (and thus the bacterial growth) had returned to similar levels to that of the untreated control by the end of the $6 \mathrm{hr}$ incubation period. This may indicate that the M. leichhardtii extract has bacteriostatic effects on B. cereus. In contrast, the growth of $K$. pneumonia growth (Figure $3 \mathrm{~b}$ ) by the methanolic $M$. leichhardtii leaf extracts was still significantly inhibited by the end of the $6 \mathrm{~h}$ time course study. Indeed, the turbidity had not significantly increased throughout the $6 \mathrm{hr}$ growth period, indicating the extract may be bacteriocidal towards K. pneumoniae at the dose tested.

\section{Quantification of toxicity}

The toxicity of the M. leichhardtii extracts was initially tested undiluted in the Artemia franciscana nauplii bioassay (Figure 4). The mortality in the presence of the extract was not significantly different to that of the untreated control at $24 \mathrm{~h}$ and thus were deemed to be non-toxic Extracts with $24 \mathrm{hr} \mathrm{LC}$ values $>1000 \mu \mathrm{g} / \mathrm{mL}$ have previously been defined as non-toxic. ${ }^{22}$ In contrast, the potassium dichromate positive control induced substantial mortality within $4 \mathrm{~h}$ (results not shown), with $100 \%$ mortality induction seen by $24 \mathrm{~h}$. By $48 \mathrm{~h}$, the mortality induction had also increased for the $M$. leichhardtii extract. However, the \% mortality was still substantially $<1000 \mu \mathrm{g} / \mathrm{mL}$.

\section{DISCUSSION}

Plant derived remedies are increasingly sought after in the treatment of a myriad of diseases and disorders due both to their perception of greater safety than synthetic drugs and the failure of some current drug regimens to effectively treat disease. Our study reports on the growth inhibitory properties of a methanolic $M$. leichhardtii leaf extract against 
Table 2: Minimum inhibitory concentrations $(\mu \mathrm{g} / \mathrm{mL})$ of the $M$. leichhardtii leaf extracts against each bacterial species and $L_{50}$ values $(\mu \mathrm{g} / \mathrm{mL})$ against Artemia nauplii.

\begin{tabular}{|c|c|c|c|}
\hline & Bacteria & Exposure time (h) & MIC or LC50 $(\mu \mathrm{g} / \mathrm{mL})$ \\
\hline & K. pneumoniae & 24 & 388 \\
\hline 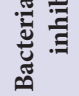 & B. cereus & 24 & 3678 \\
\hline \multirow{3}{*}{ 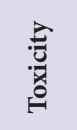 } & \multirow{3}{*}{$\mathrm{LC}_{50}(\mu \mathrm{g} / \mathrm{mL})$} & 24 & CND \\
\hline & & 48 & CND \\
\hline & & 72 & 946 \\
\hline
\end{tabular}

Numbers indicate the mean MIC or $\mathrm{LC}_{50}$ values of three independent experiments in triplicate $(\mathrm{n}=9)$. CND indicates that an $\mathrm{LC}_{50}$ could not be determined as the mortality did not exceed $50 \%$ at any concentration tested.
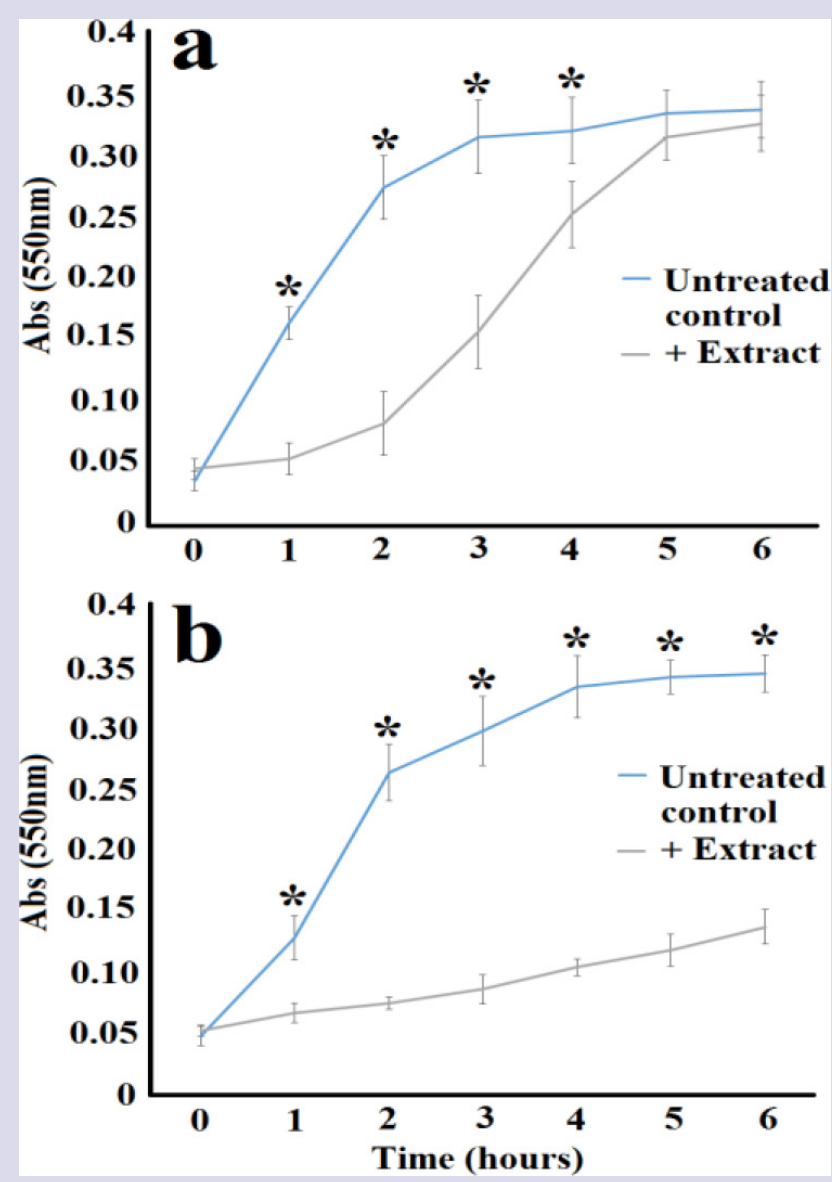

Figure 3: Bacterial growth curves for the $M$. leichhardtii extract against (a) B. cereus (clinical isolate) and (b) K. pneumoniae (ATCC31488). All bioassays were performed three times in triplicate $(n=9)$ and are expressed as mean \pm SEM. ${ }^{*}=$ results that are significantly different between the treated and the untreated control growth $(P<0.01)$

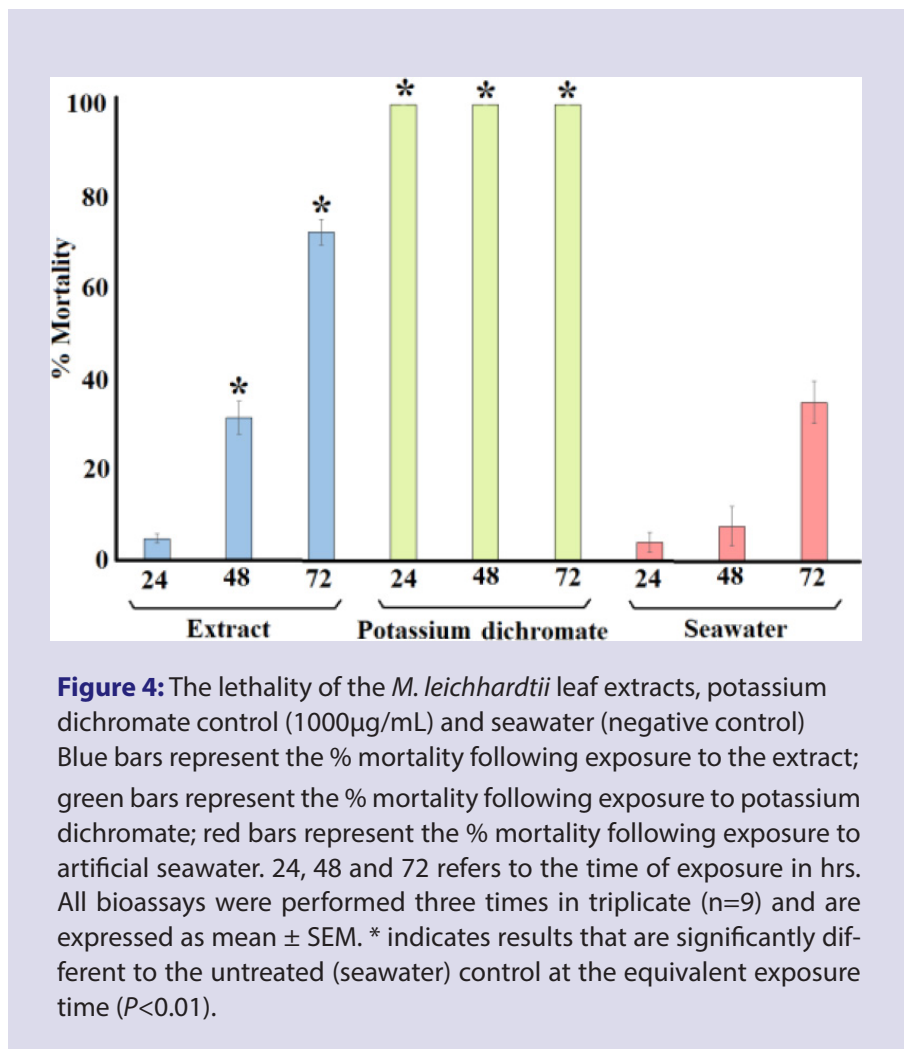

a panel of pathogenic bacteria and on its toxicity. The extract was a particularly potent inhibitors of $K$. pneumoniae growth, with an MIC value of $388 \mu \mathrm{g} / \mathrm{mL}$. As K. pneumoniae can trigger ankylosing spondylitis in genetically susceptible individuals, ${ }^{23-25}$ this extract may be useful in the prevention and treatment of the autoimmune disease. Whilst not as potent, the $M$. leichhardtii extract was also a moderate inhibitors of B. cereus growth (MICs $3678 \mu \mathrm{g} / \mathrm{mL}$ ). Therefore, the M. leichhardtii extract also has therapeutic potential in the treatment of food poisoning, diarrhoea and dysentery. None of the other bacterial species tested were inhibited by the M. leichhardtii extract, indicating that compounds in the extracts function via specific mechanisms, rather than via general membrane perturbations.

Whilst a detailed investigation of the phytochemistry of the M. leichhardtii leaf extract was beyond the scope of our study, qualitative screening studies were used to determine the classes of compounds present. Notably, the extract contained relatively high levels of total phenolics, flavonoids, tannins, triterpenoids and phytosterols. It is likely that these and other phytochemical classes may contribute to the growth inhibitory properties of the M. leichardtii extract. Our qualitative phytochemical screening studies also indicated that alkaloids were also present in the extract, albeit in low relative abundance. Many studies have reported potent antibacterial activities for a wide variety of these compounds. ${ }^{10}$ Further phytochemical evaluation studies and bioactivity driven isolation of active components is required to further evaluate the mechanism of bacterial growth inhibition.

The findings reported here also demonstrate that the $M$. leichhardtii leaf extract was non-toxic towards Artemia franciscana nauplii, with $\mathrm{LC}_{50}$ values substantially $>1000 \mu \mathrm{g} / \mathrm{mL}$. Extracts with $\mathrm{LC}_{50}$ values $>1000 \mu \mathrm{g} / \mathrm{mL}$ towards Artemia nauplii are defined as being nontoxic. ${ }^{22}$ Whilst our preliminary toxicity studies indicate that these extracts may be safe for therapeutic use, studies using human cell lines are required to further evaluate the safety of these extracts. Furthermore, whilst these studies have demonstrated the potential of the M. leichhardtii leaf extracts in the 
development of future antibiotic chemotherapeutics (particularly for the prevention and of ankylosing spondylitis in genetically susceptible people, as well as other disease caused by K. pneumoniae infections), more work is required to isolate the inhibitory components and determine the mechanism of inhibition. Whilst these studies have demonstrated the potential of the methanolic M. leichhardtii leaf extract in the development of future antibiotic chemotherapeutics, more work is required to isolate the inhibitory components and determine the mechanism of inhibition.

\section{CONCLUSION}

The results of this study demonstrate the potential of the M. leichhardtii leaf extracts as an inhibitor of the growth of some pathogenic bacteria (especially K. pneumoniae). Furthermore, their lack of toxicity indicates that they are safe for internal as well as topical treatment. Further studies aimed at the purification and identification of bioactive components are required to examine the mechanisms of action of these agents.

\section{ACKNOWLEDGEMENT}

The authors are grateful to Philip Cameron for identifying and providing the plant material used in this study. We are also grateful to Michelle Mendell and Jane Gifkins for the gift of the clinical isolate bacterial strains. Financial support for this work was provided by the Environmental Futures Research Institute and the School of Natural Sciences, Griffith University, Australia.

\section{CONFLICT OF INTEREST}

The authors report no conflicts of interest.

\section{ABBREVIATIONS}

DMSO: Dimethyl sulfoxide; $\mathbf{L C}_{50}$ : The concentration required to achieve 50 \% mortality; MIC: Minimum inhibitory concentration; ZOI: Zone of inhibition.

\section{REFERENCES}

1. Cowan MM. Plant products as antibacterial agents. Clinical Microbiology Reviews. 1999;12(4):564-82.

2. Bhavnani SM, Ballow $\mathrm{CH}$. New agents for Gram-positive bacteria. Current Opinion in Microbiology. 2000;3(5):528-34.

3. Chiariandy $\mathrm{CM}$, Seaforth $\mathrm{CE}$, Phelps $\mathrm{RH}$, et al. Screening of medicinal plants from Trinidad and Tobago for antimicrobial and insecticidal properties. Journal of Ethnopharmacology. 1999;64(3):265-70.

4. Patwardhan B, Warude D, Pushpangadan $\mathrm{P}$, et al. Ayurveda and traditional Chinese medicine: a comparative overview. Evidence-based Complimentary and Alternative Medicine. 2005;2(4):465-73.

5. Hostettmann K, Marston A, Ndjoko K, et al. The potential of African plants as a source of drugs. Current Organic Chemistry. 2000;4(10):973-1010.

6. Paz EA, Cerdeiras MP, Fernandez J, et al. Screening of Uruguayan medicinal plants for antimicrobial activity. Journal of Ethnopharmacology. 1995;45(1):67-70.
7. Cock IE. Medicinal and aromatic plants - Australia. In Ethnopharmacology, Encyclopedia of Life Support Systems (EOLSS), Developed under the auspices of UNESCO. Oxford, UK: EOLSS Publishers. 2011. Available from: http://www. eolss.net.

8. Collins DJ, Culvenor CCJ, Lambertson DJ, et al. Plants for Medicines. A Chemical and Pharmacological Survey of Plants of the Australian Region. CSIRO; East Melbourne, Australia. 1990.

9. Brophy JJ, Goldsack RJ, Foster PI. The leaf oils of the Queensland species of Melodorum (Annonaceae). Journal of Essential Oil Research. 2004;16(5):483-6.

10. Cock IE. The phytochemistry and chemotherapeutic potential of Tasmannia lanceolata (Tasmanina pepper): A review. Pharmacognosy Communications. 2013;3(4):13-25. DOI: 10.5530/pc.2013.4.3

11. Boyer $\mathrm{H}$, Cock IE. Evaluation of the potential of Macademia integriflora extracts as antibacterial food agents. Pharmacognosy Communications. 2013;3(3):53-62. DOI: $10.5530 / p c .2013 .3 .10$

12. Courtney R, Sirdaarta J, Matthews B, et al. Tannin components and inhibitory activity of Kakadu plum leaf extracts against microbial triggers of autoimmune inflammatory diseases. Pharmacognosy Journal. 2015;7(1):18-31. DOI: 10.5530/ pj.2015.7.2

13. Hart C, Ilanko P, Sirdaarta J, et al. Tasmannia stipitata as a functional food/natural preservative: Antimicrobial activity and toxicity. Pharmacognosy Communications. 2014;4(4):33-47. DOI: 10.5530/pc.2014.4.4

14. Mpala L, Chikowe G, Cock IE. No evidence of antiseptic properties and low toxicity of selected Aloe species. Journal of Pharmaceutical Negative Results. 2010;1(1):10-6. DOI: 10.4103/0976-9234.68869

15. Sirdaarda J, Matthews B, White A, et al. GC-MS and LC-MS analysis of Kakadu plum fruit extracts displaying inhibitory activity against microbial triggers of multiple sclerosis. Pharmacognosy Communications. 2015;5(2):100-15. DOI: 10.5530/pc.2015.2.2

16. Kalt FR, Cock IE. Gas chromatography-mass spectroscopy analysis of bioactive Petalostigma extracts: Toxicity, antibacterial and antiviral activities. Pharmacognosy Magazine. 2014;10(Suppl 1):S37-49. DOI: 10.4103/0973-1296.127338

17. Vesoul J, Cock IE. The potential of Bunya nut as an antibacterial food agent. Pharmacognosy Communications. 2012;2(1):72-9. DOI: 10.5530/pc.2012.1.13

18. Arkhipov A, Sirdaarta J, Rayan $P$, et al. An examination of the antibacterial, antifungal, anti-Giardial and anticancer properties of Kigelia africana fruit extracts. Pharmacognosy Communications. 2014;4(3):62-76. DOI: 10.5530/pc.2014.3.7

19. Cock IE. Antimicrobial activity of Acacia aulacocarpa and Acacia complanta methanolic extracts. Pharmacognosy Communications. 2012;2(1):66-71. DOI: 10.5530/pc.2012.1.12

20. Cock IE. Assessment of the toxicity of selected Australian native plant extracts using the Artemia franciscana nauplii bioassay. Internet Journal of Toxicology. 2008;5(2):2

21. Ruebhart DR, Wikramasinghe WA, Cock IE. Protective efficacy of the antioxidants vitamin E and Trolox against Microcystis aeruginosa and microcystin-LR in Artemia franciscana nauplii. Journal of Toxicology and Environmental Health Part A. 2009;72(24):1567-75

22. Cock IE, Ruebhart DR. Comparison of the brine shrimp nauplii bioassay and the ToxScreen-II test for the detection of toxicity associated with Aloe vera (Aloe barbadensis Miller) leaf extract. Pharmacognosy Research. 2009;1(2):98-101.

23. Schwimmbeck PL, Yu DTY, Oldstone MBA. Auto-antibodies to HLA-B27 in the sera of HLA-B27 patients with ankylosing spondylitis and Reiter's syndrome: molecular mimicry with Klebsiella pneumoniae as a potential mechanism of autoimmune disease. J Exp Med. 1987;166(1):173-81.

24. Ebringer $A$, Rashid T, Wilson $C$, et al. Ankylosing spondylitis as an auto-immune disease linked to intestinal Klebsiella infection: prospects for a new therapeutic approach. Curr Rheum Rev. 2006;2(1):55-68.

25. Fielder M, Pirt SJ, Tarpey I, et al. Molecular mimicry and ankylosing spondylitis: possible role of a novel sequence in pullulanase of Klebsiella pneumoniae. Febs Lett. 1995;369(2-3):243-8.

\section{SUMMARY}

- M. leichardtii methanolic leaf extract displayed antibacterial activity against $B$. cereus and K. pneumoniae.

- The extract was a particularly potent inhibitor of $K$. pneumoniae growth (MIC $388 \mu \mathrm{g} / \mathrm{mL}$ ).

- B. cereus was also susceptible to the extract, albeit with substantially higher MIC values $(3678 \mu \mathrm{g} / \mathrm{mL})$

- The methanolic M. leichardtii leaf extract was nontoxic in the Artemia nauplii bioassay. 
PICTORIAL ABSTRACT

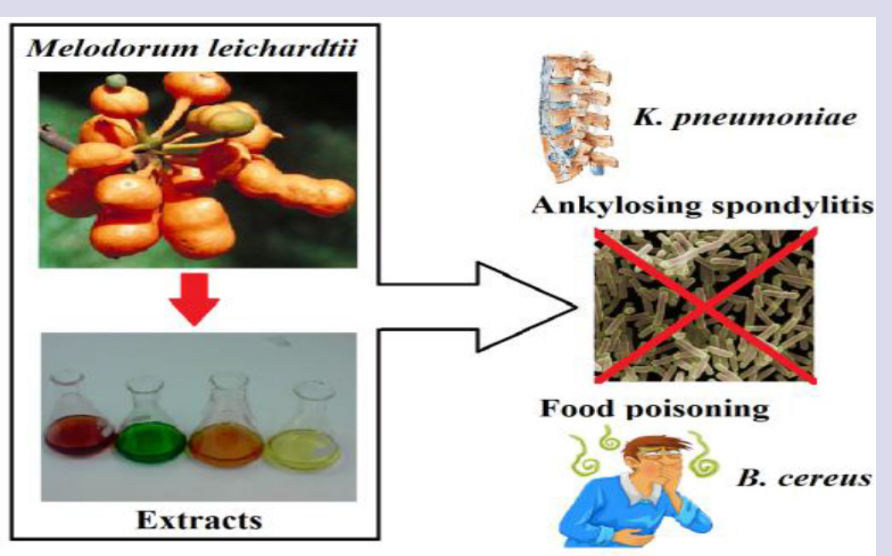

ABOUT AUTHORS

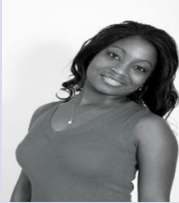

Author profile (Getmore Rumbudzai Chikowe): Ms Getmore Chikowe completed at BSc at Griffith University in life sciences. Following graduation, she undertook a research project in Dr lan Cock's laboratory in the School of Natural Sciences at Griffith University. The project examined the growth inhibitory properties of a variety of Australian native plants against an extensive panel of bacterial pathogens.

Author profile (Lindiwe Nomathemba Mpala): Ms Lindiwe Mpala completed at BSc at Griffith University in life sciences. Following graduation, she undertook a research project in Dr lan Cock's laboratory in the School of Natural Sciences at Griffith University. The project examined the growth inhibitory properties of a variety of Australian native plants against an extensive panel of bacterial pathogens.

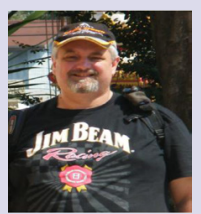

Author profile (Dr lan Cock): Dr lan Cock leads a research team in the Environmental Futures Research Institute and the School of Natural Sciences at Griffith University, Australia. His research involves bioactivity and phytochemical studies into a variety of plant species of both Australian and international origin, including Aloe vera, South Asian and South American tropical fruits, as well as Australia plants including Scaevola spinescens, Pittosporum phylliraeoides, Terminalia ferdinandiana (Kakadu plum), Australian Acacias, Syzygiums, Petalostigmas and Xanthorrhoea johnsonii (grass trees). This range of projects has resulted in nearly 200 publications in a variety of peer reviewed journals. 